\title{
Dominant yeasts associated to mango (Mangifera indica) and rose apple (Syzygium malaccense) fruit pulps investigated by culture-based methods
}

\author{
MAURICIO RAMÍREZ-CASTRILLÓN ${ }^{1}$, LUISA M. USMAN ${ }^{2}$, LINA M. \\ SILVA-BEDOYA $^{3}$ and ESTEBAN OSORIO-CADAVID ${ }^{2}$
}

\author{
${ }^{1}$ Facultad de Ciencias Básicas, Universidad Santiago de Cali, Calle 5, 62-00 Cali, Valle del Cauca, Colombia \\ ${ }^{2}$ Departamento de Biología, Facultad de Ciencias Naturales y Exactas, Universidad \\ del Valle, Calle 13, 100-00 Cali, Valle del Cauca, Colombia \\ ${ }^{3}$ Maestría en Ciencias Biotecnología, Universidad Nacional de Colombia, sede \\ Medellín, Carrera 65, 59A-110 Medellín, Antioquia, Colombia
}

Manuscript received on January 17, 2019; accepted for publication on July 2, 2019

\begin{abstract}
How to cite: RAMÍREZ-CASTRILLÓN M, USMAN LM, SILVA-BEDOYA LM AND OSORIO-CADAVID E. 2019. Dominant yeasts associated to mango (Mangifera indica) and rose apple (Syzygium malaccense) fruit pulps investigated by culture-based methods. An Acad Bras Cienc 91: e20190052. DOI 10.1590/0001-3765201920190052.
\end{abstract}

\begin{abstract}
The biotechnological potential of yeasts associated to different habitats in Colombia has been poorly studied, especially the yeasts associated with different plant structures. Fruit pulps are interesting substrates mainly for the growth of yeast species, that can positively affect the productivity and quality of some bioeconomic species. Therefore, the objective of this study was to identify the dominant yeast species associated with mango and rose apple fruit pulps in Cali, Colombia. A total of 90 isolates were obtained, which were grouped considering their colony morphology. The D1/D2 domain of the large ribosomal RNA gene (LSU rRNA gene) or internal transcribed spacer (ITS) 1, ribosomal gene 5.8S and ITS 2 (ITS) regions of one to several representative isolates from each group was sequenced and compared with type strains for identification. The species Hanseniaspora thailandica, H. opuntiae and Clavispora lusitaniae were reported as shared by both fruits, specific for rose apple (H. uvarum, Pichia terricola, Rhodosporidiobolus ruineniae and Candida albicans), or for Mango (Meyerozyma caribbica, M. guilliermondii, C. natalensis, Aureobasidium pullulans, Pichia sp., Saturnispora diversa and C. jaroonii). Two morphotypes were not identified at the taxonomic level of species and were reported as candidates for new species, belonging to the genera Wickerhamomyces and Pichia.
\end{abstract}

Key words: Mangifera indica, Syzygium malaccense, molecular identification, yeasts, Colombia.

\section{INTRODUCTION}

Yeasts have been reported in almost all natural and artificial ecosystems. The conditions that prevail in each substrate determine the ecology, metabolic activity, growth and survival of different yeast

Correspondence to: Mauricio Ramírez-Castrillón

E-mail: mauricio.ramirez00@usc.edu.co

ORCid: https://orcid.org/0000-0001-8525-5341 species (Deak 2009). Fruits, composed mainly of water and carbohydrates, provide an ideal environment for the growth and maintenance of ascomycetous yeasts. Mango (Mangifera indica) and the rose apple (or "Pomarroso" in Colombia, Syzygium malaccense) are highly nutritional fruits that contain carbohydrates, proteins, fats, minerals and vitamins, specifically vitamin A (beta carotene), 
B1, B2, and vitamin C (ascorbic acid) (at: http:// www.traditionaltree.org/). As the fruit matures, vitamin $\mathrm{C}$ concentrations decrease, and glucose, fructose and sucrose levels increase (reported here as ${ }^{\circ}$ Brix), which can be used by fermentative yeasts. In this sense, the fermentative capacity, enzymatic activity and other physiological properties of yeasts are of interest and have been extensively explored in other countries (Pampulha and Loureiro 1989, Palnitkar and Lachke 1990, Mejía et al. 2009, Thierfelder et al. 2011). However, in Colombia the composition or biotechnological potential of these yeasts is less documented (Ulloa et al. 2009).

Colombia has been widely recognized as a center of mega-biodiversity at the level of both plant and animal species, a situation that is determined thanks to its privileged variety of ecological niches. This condition allows intuiting the presence of an equally mega-diverse profile in the population of microorganisms in our territory (Velez 2009). Few reports in the literature analysed the diversity of yeasts associated with mango or rose apple. In the case of mango, Gaviria and Osorio (2012) identified the yeasts associated with mango inflorescences in the same region (Cali, Colombia), finding 13 different species. These results suggest the possibility that some of these species may possibly be shared in the pulp of the fruit. Similarly, Jager et al. (2001) evaluated the yeasts of the mango phylloplane, finding species of the genera Aureobasidium, Cryptococcus, and Sporobolomyces. On the other hand, Trujillo and Echeverry (2015) evaluated the yeasts associated with the rose apple in the Department of Huila (Colombia), identifying 6 groups at the genus level and 4 unidentified morphotypes. The main drawback they had was the identification using biochemical methods, which did not allow the identification to the species level, and therefore did not have comparable results. In this way, evaluating yeasts associated with different plant structures is of great interest, not only to understand their ecological role, perpetuity in plants or even possible co-evolution, but also to find strains that may be of biotechnological interest (Ulloa et al. 2009).

The identification of yeasts should be carried out using molecular methods such as the sequence analysis of ribosomal regions, such as the D1/D2 domain of the LSU rRNA gene and ITS region, and different thresholds would be compared with type strain sequences for identification at the species level (Kurtzman et al. 2015). In this sense, $\mathrm{Vu}$ et al. (2016) analysed the sequences of both regions of the entire yeast collection belonging to the Westerdijk Fungal Biodiversity Institute and determined an identity threshold of $98.41 \%$ for the ITS region (98.31\% for Ascomycetes and 98.61\% for Basidiomycetes) and an identity threshold of $99.51 \%$ for the D1/D2 domain of the LSU rRNA gene (99.41\% for Ascomycetes and 99.51 for Basidiomycetes) as optimal cut-off criteria to reach the species level. Thus, the objective of this work was to identify the dominant community of yeasts associated with mango and rose apple fruit pulps in Santiago de Cali, Colombia, using sequence-based analysis.

\section{MATERIALS AND METHODS}

\section{SAMPLING AND YEAST ISOLATION}

Yeasts were obtained between 2010 and 2011 from the pulps of mango and rose apple (or "pomarroso") fruits in Santiago de Cali, Colombia. This city is framed within a climate of tropical valley, with precipitation up to $1200 \mathrm{~mm}$, average temperature of $26^{\circ} \mathrm{C}$, minimum of $19^{\circ} \mathrm{C}$ and maximum of $34^{\circ} \mathrm{C} .50$ mangoes were picked from a fruit distribution center (origin of mangoes: Valle del Cauca, Colombia) and 50 rose apples were randomly collected at Universidad del Valle. Each fruit was collected in sterile bags and immediately transported under refrigeration to the laboratory of molecular biology of microorganism at Universidad del Valle. The individual fruits were classified following Bartrina 
(2006) and sorted according to their coloration resulting in 10 healthy orange-yellow mango fruits $(\mathrm{n}=10)$ and 15 magenta-crimson rose apples $(\mathrm{n}=$ 15) being analysed.

To clean the exterior of the fruits and avoid contaminating the pulp, the fruits were sterilized by washing them for one minute in three consecutive solutions. First, a wash of one minute with hypochlorite $(1.5 \% \mathrm{v} / \mathrm{v})$, then one minute with $70 \%$ ethanol (v/v) and finally one minute with sterile distilled water. The skin was removed, and the pulp homogenized. The Brix degrees were measured in the macerated fruit product using a manual refractometer (RHB Westover 32ATC, USA). Twenty-five grams of pulp extract were mixed in $50 \mathrm{~mL}$ malt extract medium $(20 \mathrm{~g} / \mathrm{L}$ of malt extract, $20 \mathrm{~g} / \mathrm{L}$ of glucose and $1 \mathrm{~g} / \mathrm{L}$ of peptone) and incubated at $28^{\circ} \mathrm{C}$ for $48 \mathrm{~h}$ on a rotary shaker at $150 \mathrm{rpm}$.

After the enrichment step, serial dilutions were made in peptone water and the $10^{-1}$ to $10^{-3}$ dilutions for mango, and the $10^{-4}$ to $10^{-6}$ for rose apple were plated in yeast peptone dextrose agar (YPDA) medium $(10 \mathrm{~g} / \mathrm{L}$ yeast extract, $20 \mathrm{~g} / \mathrm{L}$ mycological peptone, $20 \mathrm{~g} / \mathrm{L}$ glucose and $20 \mathrm{~g} / \mathrm{L}$ agar; ascomycete yeasts) and malt extract agar (MEA) (20 g/L malt extract, $20 \mathrm{~g} / \mathrm{L}$ glucose, $1 \mathrm{~g} / \mathrm{L}$ peptone and $15 \mathrm{~g} / \mathrm{L}$ agar; basidiomycete yeasts), both supplemented with $25 \mathrm{mg} / \mathrm{L}$ of ampicillin and chloramphenicol to inhibit bacterial growth. The plates were incubated at room temperature for 48 hours and five to ten representative colonies of each plate were subsequently isolated and purified through several repetitions of streaking on YPDA or MEA culture medium. Finally, the isolates were preserved using a mixture of YPD medium (70\%) and glycerol (30\%) and stored at $-20^{\circ} \mathrm{C}$ until further analysis.

\section{MORPHOLOGICAL CHARACTERIZATION AND DNA SEQUENCING}

All isolates were characterized for colony and cell morphology using a light microscope (Olympus
CH30, USA). The following criteria were considered: shape, elevation, margin of the colony, cell shape and type of asexual reproduction. This data was used to group the isolates by morphotypes.

DNA extraction was performed according to Osorio-Cadavid et al. (2009). The concentration and purity of the DNA were determined by spectrophotometry at $260 \mathrm{~nm}$ and $260 \mathrm{~nm} / 280 \mathrm{~nm}$ ratio using a Nanodrop 2000 (Thermo Scientific $\AA$ v1.0 USA) and by agarose gels $(1 \% \mathrm{w} / \mathrm{v})$, stained with ethidium bromide $1.5 \%(\mathrm{w} / \mathrm{v})$ and excited at $240 \mathrm{~nm}$.

The sequencing of the D1/D2 domain of the LSU rRNA gene or ITS region of representative isolates from each morphological group was carried out according to Kurtzman et al. (2015). For the amplification of the the D1/D2 domain of the LSU rRNA gene, primers NL1 (5'-GCATATCAATAAGCGGAGGAAAAG-3') and NL4 (5'-GGTCCGTGTTTCAAGACGG-3') were used. For the ITS region, primers ITS 5 ( $5^{\prime}$-GGAAGTAAAAGTCGTAACAAGG-3') and ITS4 (5' -TCCTCCGCTTATTGATATGC-3') were used. The reactions were performed in a thermal cycler (Multigene-Labnet, USA) under the following conditions: initial denaturation at $94^{\circ} \mathrm{C}$ for $5 \mathrm{~min}, 30$ cycles of denaturation at $94^{\circ} \mathrm{C}$ for 1 min, pairing at $55^{\circ} \mathrm{C}$ for 30 seconds, and extension at $72^{\circ} \mathrm{C}$ for $1 \mathrm{~min}$, with a final extension of $10 \mathrm{~min}$ at $72^{\circ} \mathrm{C}$ (Osorio-Cadavid et al. 2008).

The PCR products were purified and sequenced by Macrogen (USA) and Corpogen (Colombia) under standardized conditions. Subsequently, the sequences were manually edited, assembled and compared to the sequence of the type strain reported in GenBank using the BLAST algorithm. Sequences with identity equal to or greater than $99 \%$ were identified at the taxonomic level of species. Strains LUM023, LUM031 (the D1/D2 domain of the LSU rRNA gene) and LUM055 (ITS) were identified using phylogenetic analysis. First, we determined the best substitution model for 
each alignment (Clustal W). Second, we used the Maximum Likelihood method with all sites, and a bootstrap test of 1000 replicates. All phylogenetic trees were constructed with the software MEGA X (®)

This article does not contain any studies with human participants performed by any of the authors.

\section{RESULTS}

A total of 90 representative isolates were obtained, out of which 48 were isolated from rose apple and 42 from mango. The rose apples were classified in three groups according to their Brix degrees (or ${ }^{\circ}$ Brix): less than $8^{\circ}$ Brix (three samples), between 8.1 and $10^{\circ}$ Brix (eight samples), between 10.1 and $12{ }^{\circ} \mathrm{Brix}$ (five samples). In total, 15 rose apples were selected from the 50 fruits randomly sampled. For mango, four intervals were determined: less than or equal to $12^{\circ} \mathrm{Brix}$ (one sample), 15 to $15.9^{\circ} \mathrm{Brix}$ (three samples), 16 to $16.9^{\circ} \mathrm{Brix}$ (two samples), and $20^{\circ}$ Brix or higher (four samples). In total, 10 mango fruits were selected and analysed from the 50 sampled fruits. Table I shows the number of isolates obtained from each range of dissolved sugars per fruit.

\section{YEAST IDENTIFICATION}

Groupings were made considering both the colony and cell morphologies of the isolates to facilitate their identification. The isolates obtained from rose apples were divided into 8 groups (morphotypes) and the ones from mango fruits into 13 morphotypes.

One to five representative isolates from each morphotype (or single isolates if it was the case), were identified by comparing the sequence of the the D1/D2 domain of the LSU rRNA gene or ITS region with the type strain sequences deposited in the GenBank database. For rose apples, eight different species were identified within the genera Hanseniaspora, Pichia, Rhodosporidiobolus,
TABLE I

Sample distribution by Brix degrees ranges and number of isolates for each selected sample and range.

\begin{tabular}{ccc}
\hline Range & Number of samples & Number of isolates \\
\hline & Rose Apple \\
\hline$<8^{\circ}$ Brix & 2 & 15 \\
$8.1-10^{\circ}$ Brix & 8 & 25 \\
$10.1-12^{\circ}$ Brix & 5 & 8 \\
Total & 15 & 48 \\
\hline & Mango & \\
\hline$\leq 12^{\circ}$ Brix & 1 & 10 \\
$15-15.9^{\circ}$ Brix & 3 & 23 \\
$16-16.9^{\circ}$ Brix & 2 & 7 \\
$>20^{\circ}$ Brix & 4 & 2 \\
Total & 10 & 42 \\
\hline
\end{tabular}

Rhodotorula, Candida and Clavispora (Table II, Figure 1). For mango, 11 species were identified, belonging to the genera Hanseniaspora, Candida, Clavispora, Meyerozyma, Aureobasidium and Pichia (Table II, Figure 1). The sequences of the representative isolates for each morphotype were deposited in the GenBank database (Table II). Groups M6 and M7 could not be identified at the taxonomic level of species by sequence comparison and are therefore reported as candidates for a new species within the genera Wickerhamomyces (Figure S1 - Supplementary Material) and Pichia (Figure S2), according to the phylogenetic analysis.

According to Figure 1, both fruits shared three yeast species: Hanseniaspora thailandica, H. opuntiae and Clavispora lusitaniae. The most dominant species in rose apple and mango were $H$. thailandica and Wickerhamomyces sp., respectively. Other species, such as Candida natalensis, Aureobasidium melanogenum, Pichia sp., Saturnispora diversa, Hanseniaspora opuntiae and $H$. thailandica only had one isolate each in mango. In rose apple, the species Rhodosporidiobolus ruineniae had one isolate, followed by $A$. thailandense, Clavispora lusitaniae and $H$. opuntiae with two isolates per species. 


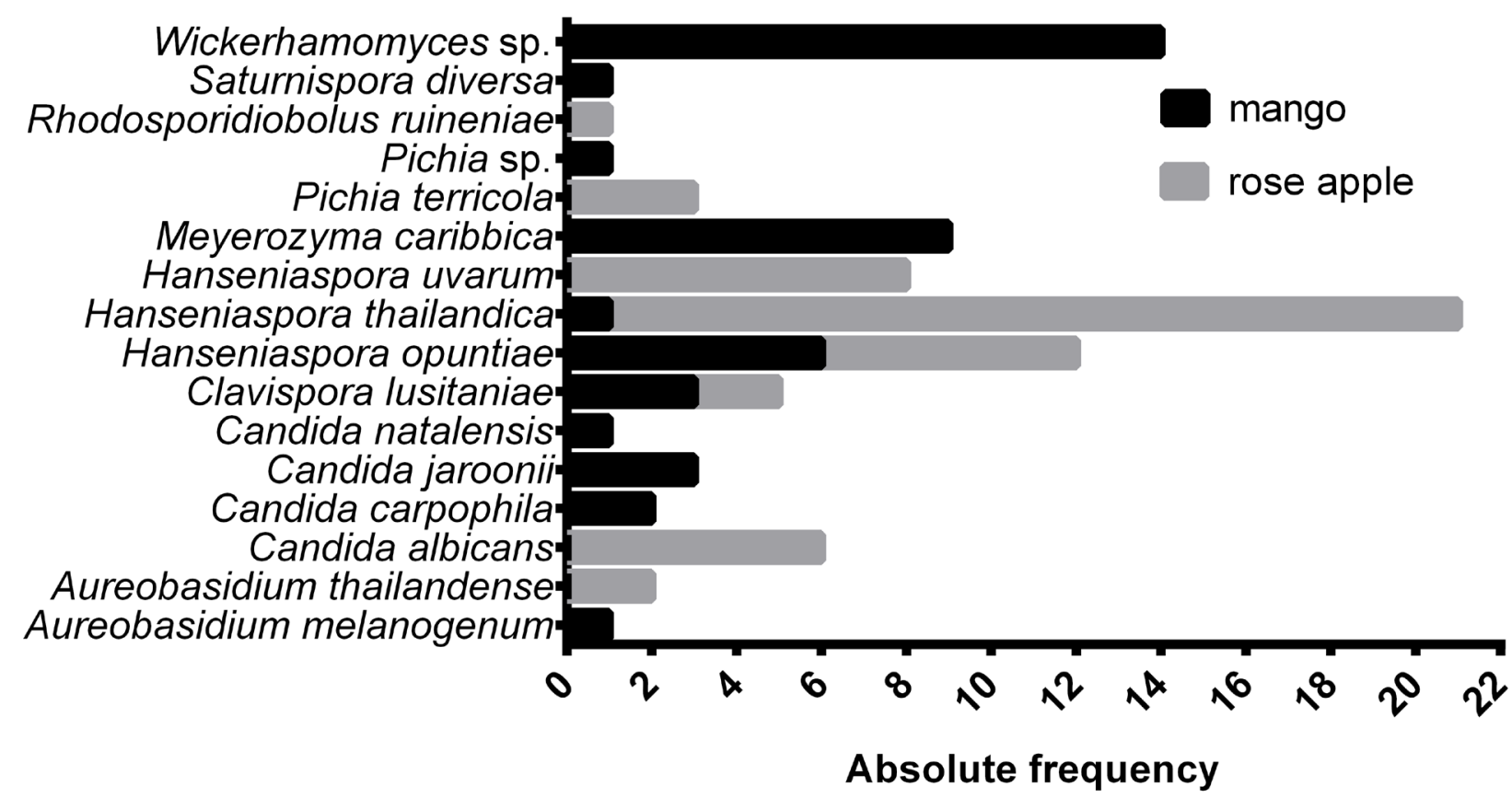

Figure 1 - Absolute frequency of yeast species obtained from mango and rose apple pulps. Each value corresponded to the sum of the strains isolated for each species.

The distribution of species and isolates by ranges of ${ }^{\circ}$ Brix was analysed (Figure 2). Isolates of the species Wickerhamomyces sp. were found in all ranges of ${ }^{\circ}$ Brix for mango. In rose apple, $H$. uvarum was isolated in most ranges, except for values equal to or greater than $20^{\circ} \mathrm{Brix}$. In the range from 15 to $15.9^{\circ}$ Brix for mango, 18 isolates from five different species were obtained, which suggests that it is the range of dissolved sugars with the highest yield in terms of richness of ascomycete yeasts (Figure 2). For rose apple, most species, except Clavispora lusitaniae, were found in the range of 8.1 to 10 ${ }^{\circ}$ Brix, followed by the rank equal to or less than 8 ${ }^{\circ}$ Brix, which presented half of the identified species for this fruit.

\section{DISCUSSION}

\section{ANALYSIS OF SAMPLING AND GROUPING}

In this work two culture media namely YPDA and MEA were used, with the intention of promoting the growth of dominant ascomycetes and basidiomycetes yeasts from mango and rose apple, respectively. It should be noted that the sampling and development of the research was culturedependent, so the analyses of different species found are biased by the type of methodology used. According to Baxter and Van der Linde (1999), the MEA is the most suitable medium for the growth of most basidiomycetes. On the other hand, culture media such as GYP or YPD are widely used in methods for obtaining ascomycete yeasts, such as Saccharomyces cerevisiae (Ausubel 2002).

The grouping of isolates and the subsequent identification of group representatives is a common practice in laboratories with limited economic resources. According to Vásquez et al. (2016), several characteristics are used for this purpose, depending on the aim of the project, and one or more techniques can be selected at the same time. Among them, the most used is morphological characterization and genetic profiling (for example Microsatellite-Primed-PCR Fingerprinting). Considering the high biodiversity present in Colombia and the little research done on the 
TABLE II

Morphotypes and identified yeast species using molecular identification.

\begin{tabular}{|c|c|c|c|c|c|c|}
\hline Morphotype $^{1}$ & Isolates & $\begin{array}{c}\text { Number } \\
\text { of isolates }\end{array}$ & Species & $\begin{array}{l}\text { Identity with } \\
\text { type strain }\end{array}$ & LSU GenBank & ITS GenBank \\
\hline & & & & & accession & accession \\
\hline M1 & $\begin{array}{l}\text { LUM035*, LUM043, } \\
\text { LUM045, LUM048, } \\
\text { LUM050, LUM051 }\end{array}$ & 6 & $\begin{array}{l}\text { Hanseniaspora } \\
\text { opuntiae }\end{array}$ & $99 \%$ & MH892857 & \\
\hline M2 & $\begin{array}{c}\text { LUM001*, } \\
\text { LUM003*, LUM007, } \\
\text { LUM008, LUM011, } \\
\text { LUM012, }\end{array}$ & 6 & $\begin{array}{l}\text { Meyerozyma } \\
\text { caribbica }\end{array}$ & $99 \%$ & $\begin{array}{l}\text { MH892850, } \\
\text { MH892851 }\end{array}$ & \\
\hline M4 & $\begin{array}{c}\text { LUM009*, LUM054, } \\
\text { LUM053 }\end{array}$ & 3 & $\begin{array}{l}\text { Meyerozyma } \\
\text { caribbica }\end{array}$ & $100 \%$ & MH892853 & \\
\hline M3 & LUM005, LUM006* & 2 & Candida carpophila & $100 \%$ & MH892852 & \\
\hline M5 & $\begin{array}{c}\text { LUM024, LUM025* } \\
\text { LUM026* }\end{array}$ & 3 & $\begin{array}{l}\text { Clavispora } \\
\text { lusitaniae }\end{array}$ & $99 \%$ & & $\begin{array}{l}\text { MK367571, } \\
\text { MK367572 }\end{array}$ \\
\hline M6 & $\begin{array}{l}\text { LUM020, LUM022, } \\
\text { LUM023*, LUM030, } \\
\text { LUM033, LUM034, } \\
\text { LUM036, LUM040, } \\
\text { LUM046, LUM049, } \\
\text { LUM031*, LUM032, } \\
\text { LUM037, LUM039 }\end{array}$ & 14 & $\begin{array}{l}\text { Wickerhamomyces } \\
\text { sp. }\end{array}$ & $92 \%$ & $\begin{array}{l}\text { JQ682648, } \\
\text { JQ682649 }\end{array}$ & \\
\hline M7 & LUM055* & 1 & Pichia sp. & $94 \%$ & & MK256280 \\
\hline M8 & $\begin{array}{c}\text { LUM042*, LUM044, } \\
\text { LUM047 }\end{array}$ & 3 & Candida jaroonii & $99 \%$ & MH892858 & \\
\hline M10 & LUM014* & 1 & Candida natalensis & $99 \%$ & MH892854 & \\
\hline M11 & LUM015* & 1 & $\begin{array}{l}\text { Aureobasidium } \\
\text { melanogenum }\end{array}$ & $100 \%$ & MH892855 & \\
\hline M12 & LUM029* & 1 & Saturnispora diversa & $99 \%$ & MH892856 & \\
\hline M13 & LUM052* & 1 & $\begin{array}{l}\text { Hanseniaspora } \\
\text { thailandica }\end{array}$ & $99 \%$ & MH892859 & \\
\hline P1 & $\begin{array}{l}\text { LUP060*, LUP061, } \\
\text { LUP062, LUP063, } \\
\text { LUP064, LUP065 }\end{array}$ & 6 & Candida albicans & $99 \%$ & MH892875 & \\
\hline $\mathbf{P 2}$ & LUP059*, LUP066 & 2 & $\begin{array}{l}\text { Aureobasidium } \\
\text { thailandense }\end{array}$ & $99 \%$ & MH892874 & \\
\hline
\end{tabular}


TABLE II (continuation)

\begin{tabular}{|c|c|c|c|c|c|c|}
\hline Morphotype $^{1}$ & Isolates & $\begin{array}{c}\text { Number } \\
\text { of isolates }\end{array}$ & Species & $\begin{array}{c}\text { Identity with } \\
\text { type strain }\end{array}$ & LSU GenBank & ITS GenBank \\
\hline & & & & & accession & accession \\
\hline P3 & $\begin{array}{l}\text { LUP033*, LUP035 } \\
\text { LUP007, LUP015, } \\
\text { LUP025, LUP008 }\end{array}$ & 6 & $\begin{array}{l}\text { Hanseniaspora } \\
\text { opuntiae }\end{array}$ & $99 \%$ & MH892866 & \\
\hline P4 & $\begin{array}{l}\text { LUP020*, LUP030*, } \\
\text { LUP036*, LUP058*, } \\
\text { LUP070*, LUP068, } \\
\text { LUP076, LUP067, } \\
\text { LUP071, LUP072, } \\
\text { LUP073, LUP074, } \\
\text { LUP075, LUP037, } \\
\text { LUP034, LUP054, } \\
\text { LUP051, LUP052, } \\
\text { LUP049, LUP047 }\end{array}$ & 20 & $\begin{array}{l}\text { Hanseniaspora } \\
\text { thailandica }\end{array}$ & $99 \%$ & $\begin{array}{l}\text { MH892864, } \\
\text { MH892865, } \\
\text { MH892867, } \\
\text { MH892873, } \\
\text { MH892876 }\end{array}$ & \\
\hline P5 & $\begin{array}{l}\text { LUP004*, LUP006*, } \\
\text { LUP039*, LUP040, } \\
\text { LUP041, LUP014, } \\
\text { LUP024, LUP021 }\end{array}$ & 8 & $\begin{array}{l}\text { Hanseniaspora } \\
\text { uvarum }\end{array}$ & $99 \%$ & $\begin{array}{l}\text { MH892860, } \\
\text { MH892861, } \\
\text { MH892869, } \\
\text { MH892870 }\end{array}$ & \\
\hline P6 & LUP018*, LUP023 & 2 & $\begin{array}{l}\text { Clavispora } \\
\text { lusitaniae }\end{array}$ & $100 \%$ & MH892862 & \\
\hline P7 & $\begin{array}{l}\text { LUP046*, LUP038* } \\
\text { LUP019* }\end{array}$ & 3 & Pichia terricola & $99-100 \%$ & $\begin{array}{l}\text { MH892872, } \\
\text { MH892868, } \\
\text { MH892863 }\end{array}$ & \\
\hline P8 & LUP045* & 1 & $\begin{array}{c}\text { Rhodosporidiobolus } \\
\text { ruineniae }\end{array}$ & $99 \%$ & MH892871 & \\
\hline
\end{tabular}

${ }^{1}$ The initial letter of each isolate indicates isolation source: M (mango), P ("pomarroso" or rose apple).

* Sequenced isolates.

yeast-like communities associated with different environments, this work contributes to the knowledge of the dominant yeast species present in fruits, microhabitats with different concentration of dissolved sugars, that can provide a new source of fermentative native isolates, identified through a polyphasic approach.

The type of substrate will select the types of yeast that can grow on it by determining the nutritional sources available and is considered one of the most important ecological factors. In general, yeasts are associated with almost all types of environments, including soil, freshwater, seawater, plants and animals (Deak 2009). According to the results obtained, the culture medium MEA achieved the isolation of both basidiomycetes (with the genus Rhodosporidiobolus) and ascomycetes (H. uvarum, P. terricola and S. diversa), which agrees with Yurkov et al. (2011). When both Phyla were compared, the results showed greater richness and abundance of ascomycete yeasts than basidiomycetes. This result agrees with the literature, since it was expected that more species of ascomycetes would be found in fruits, while basidiomycetes predominate in oligotrophic environments, such as plant structures different from flowers and fruits (Trindade et al. 2002, Carrillo 2003).

According to the previous postulate, the physico-chemical composition of both mango 


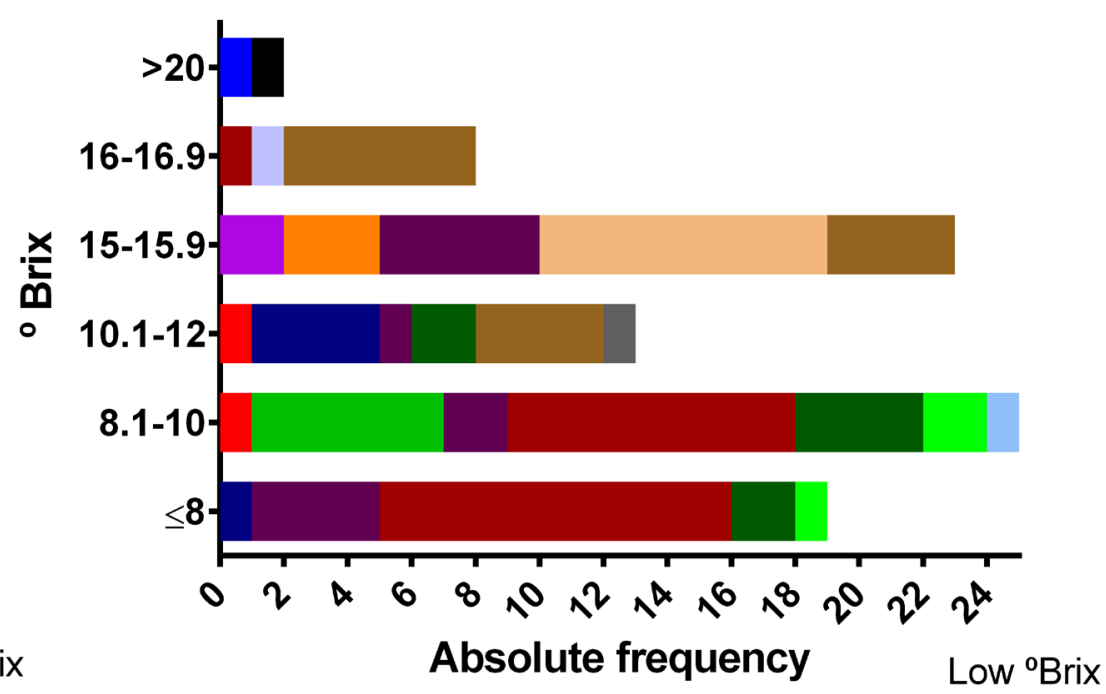

High ${ }^{\circ}$ Brix

Candida natalensis
Aureobasidium melanogenum
Saturnispora diversa
Meyerozyma caribbica
Candida carpophila
Candida jaroonii

Absolute frequency

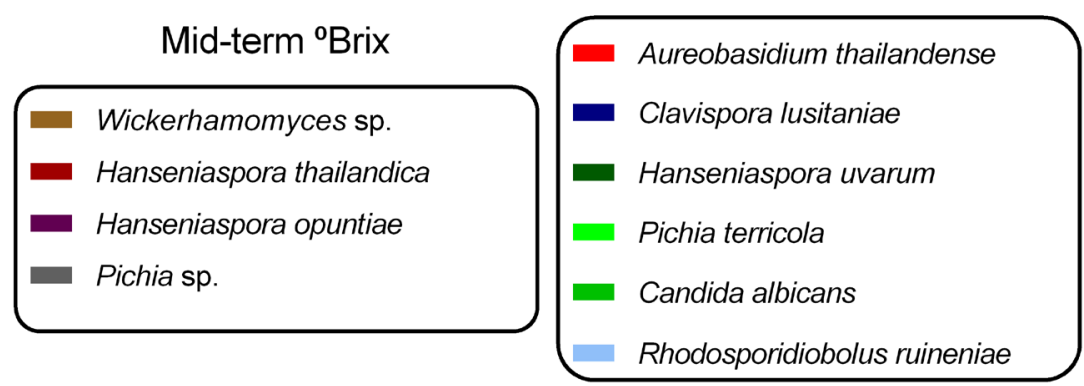

Figure 2 - Absolute frequency of yeast species found in mango and rose apple, classified according to ${ }^{\circ}$ Brix for each sample.

(Mangifera indica) and rose apple (Syzygium malaccense) provides all sources of carbon, nitrogen, minerals, vitamins and growth factors to allow the development of ascomycete yeasts (Deak 2009). This work evaluated and classified the sampled fruits according to the concentration of dissolved solids ( ${ }^{\circ} \mathrm{Brix}$ ) and found several ranges varying between 8 and $12{ }^{\circ}$ Brix for rose apple and 12-20 ${ }^{\circ}$ Brix for mango (Figure 2). The results agree with the concentrations of sugars obtained by Somda et al. (2011) and Lu et al. (2018). The species H. uvarum and Wickerhamomyces sp. were present in a wider range of ${ }^{\circ}$ Brix. Nevertheless, $H$. uvarum presented isolates in the lower range (between 8 and $12{ }^{\circ}$ Brix and specific for rose apple), suggesting that these strains tolerate a lower concentration of sugars. On the other hand, Wickerhamomyces sp. presented isolates in the range between 10 and 17 ${ }^{\circ}$ Brix, being specific for mango and associated with higher concentration of sugar content (relatively). The wide range of strains suggests that these species may be able to grow over a broad spectrum, perhaps ensuring their survival for long periods of time. The species Pichia terricola, Candida albicans and Rhodosporidiobolus ruineniae were isolated only at concentrations below $10{ }^{\circ} \mathrm{Brix}$, suggesting a possible adaptation to fruits with lower ${ }^{\circ}$ Brix.

\section{ANALYSIS OF THE YEAST COMMUNITY}

Eleven different species were isolated from mango, two of them correspond to undescribed species. The hypothesis of finding new species of ascomycete yeasts associated with Mangifera indica has already been reported. Santos et al. (2015) reported a new species associated with mango called Ogataea mangiferae, which was isolated from the phylloplane of this species in Belo Horizonte, Brazil. It should be noted that the 
species reported by Santos et al. (2015) and the two species found in this study are not conspecific (identity in sequence less than $85 \%$ ). On the other hand, nine species (A. pullulans, C. jaroonii, Cl. lusitaniae, H. thailandica, $H$. opuntiae, $K$. marxianus $M$. caribbica, M. guilliermondii and $S$. diversa) have been reported in previous studies as associated with fruits worldwide (Kurtzman et al. 2011, Buenrostro-Figueroa et al. 2018, Ting et al. 2018) or at the local level (Lopez-Arboleda et al. 2010, Mambuscay et al. 2013). Several papers reported the genus Candida in mango (Suresh et al. 1982, Feoli et al. 1997, Poubol and Izumi 2005). However, this is the first report of $C$. natalensis in fruits. S. cerevisiae was not detected in our results despite the enrichment method. The enrichment would probably increase its proliferation. The fact this species was not present suggests that possibly this species is not related with this substrate, as reported in other works (Suresh et al. 1982, Buenrostro-Figueroa et al. 2018).

The different species found in the rose apple pulp are consistent with the results obtained by Trujillo and Echeverry (2015). However, the results of this study identified yeasts up to the taxonomic level of species (using molecular tools), while Trujillo and Echeverry (2015) only managed to identify up to genera based on dichotomous keys. For example, they reported the genera Hanseniaspora, Candida, Aureobasidium (as a dimorphic fungus), Rhodotorula, Meyerozyma (reported as Pichia) and Clavispora. This is the first report of C. albicans associated to the pulp of rose apple. Since it is a human commensal yeast, and it may become pathogenic under different environmental variables, we considered the possibility of human contamination or non-aseptic conditions, but this notion was disregarded due to the fact that it did not appear associated with the mango pulp, and C. albicans was already isolated from environmental substrates at Universidad del Valle (Silva-Bedoya et al. 2014). Finally, the work of Trujillo and Echeverry (2015) reported yeasts associated with the pulp of rose apple in the city of Neiva (Huila, Colombia), which is latitudinally close to the city of Cali (Valle del Cauca, Colombia), but separated by the Central Mountain range of the Andes, which could involve a geographical barrier for the appearance of unique species for each geographical location.

The genus Aureobasidium comprises fungi with yeast-like characteristics and is widely distributed in the world (Gostinčar et al. 2014), having soils, phylloplane, bark and other plant structures, rocks, monuments and limestone as growth substrates (Urzi et al. 1999). It has also been recognized as a pollutant in paper mills, optical lenses and hypersaline habitats or coastal waters (Nagahama 2006, Li et al. 2007). It has several biotechnological applications, mainly in the generation of bioproducts for biocontrol in fruits, grains and vegetables (Di Francesco et al. 2015), as well as to produce enzymes such as amylases, lipases, alkaline proteases, hydroxylases, $\beta$-fructofuranosidases, maltosyltransferases, among others (Chi et al. 2009, Wongwatanapaiboon et al. 2016, Turk and Gostinčar 2018). This genus was already reported by Feoli et al. (1997) in their search for microorganisms with pectinolytic activity in mango, together with other species of the genus Candida. Feoli et al. (1997) used Saboraud and Nutrient agar to isolate the yeasts, suggesting that the culture media and the enrichment step affected the yeast community.

The genus Meyerozyma was described by Kurtzman and Suzuki (2010) as part of the taxonomic reorganization within the Pichiaceae clade. The species M. guilliermondii (Formerly Pichia guilliermondii) is associated with flowers, fruits and foodstuffs and it is opportunistic in humans and animals (Kurtzman et al. 2011, Corte et al. 2015).

The genus Hanseniaspora presented three species, which could correspond to the three 
morphotypes found by Trujillo and Echeverry (2015). This genus is widely distributed and frequently isolated from soil, insects and fruit musts or initial stages of fruit fermentation, even at the regional and local level (Lopez-Arboleda et al. 2010, Kurtzman et al. 2011, Gaviria and Osorio 2012, Ramirez-Castrillon et al. 2017). This genus was one of the most abundant in rose apple, fact that may be related with the concentration of dissolved solutes, which is lower when compared to mango. However, the presence of species of this genus is associated with decomposition of fruits or deterioration of fermentations (Morais et al. 1995), or positively with the release of enzymes of organoleptic interest such as glycosidases or xylosidases (Manzanares et al. 1999, Rodriguez et al. 2007). H. opuntiae and $H$. thailandica were isolated from both fruits (Figure 1). According to Ting et al. (2018), the Hanseniaspora genus is found in several fruit pulps and/or processed fruits, among them fig (Ruiz-Moyano et al. 2016), grapes (Nisiotou and Nychas 2007), pear (Ting et al. 2018), cactus (Cadez et al. 2003, Ganter et al. 2017), kiwi (Niu et al. 2015), pineapple (LopezArboleda et al. 2010, Dellacassa et al. 2017) suggesting its ubiquitous characteristic in this type of substrates. Luan et al. (2018) suggested co-fermentations of $H$. opuntiae together with $S$. cerevisiae in order to obtain organoleptically differentiated wines. In addition, Ruiz-Moyano et al. (2016) suggested H. opuntiae as a biocontrol agent for food contaminating moulds.

In the rose apple, $H$. thailandica was the most abundant species, in contrast to mango that only presented an isolate. This species has been reported in different substrates, such as phylloplane (Limtong and Nasanit 2017), lakes (Silva-Bedoya et al. 2014), lichen, flowers and decaying fruits of guava (Jindamorakot et al. 2009). Groenewald et al. (2017) reported this species as one of the most abundant in crop collections associated with fruits. The presence of this species in the lakes of the Universidad del Valle, as well as in the fruits of plants associated with these lakes, suggest a possible co-location of these species due to the fall of the fruits to the lakes and their subsequent survival in aquatic environments (Silva-Bedoya et al. 2014). Subsequent studies should evaluate if this hypothesis can be established.

$R$. ruineniae has few reports in South America. This species has only been reported by GuamánBurneo and Carvajal-Barriga (2009) in forest environments of Ecuador, while Maciel et al. (2013) isolated from coconut water and reconstituted juices in Belo Horizonte, Brazil. It is possible that several taxonomic changes in this species make the traceability of their isolation difficult. However, its report in few works suggests its low frequency or low sampling effort in this type of substrates.

Our results showed the presence of $\mathrm{Cl}$. lusitaniae associated with mango and rose apple pulps. The species $\mathrm{Cl}$. lusitaniae has been reported previously associated with mango phylloplane (Rao et al. 2008, Limtong and Koowadjanakul 2012) and other plant species, such as cactus (Starmer et al. 1990), fig (Ficus carica), guava (Psidium guajava) or banana (Musa paradisiaca) (Limtong and Koowadjanakul 2012). It has also been reported as the most abundant species associated with acetic rot at the base of the agave leaves used to produce Tequila (Kurtzman et al. 2011). Finally, Trujillo and Echeverry (2015) also found it associated with rose apple in Neiva (Huila, Colombia).

In conclusion, the community of yeasts associated with the fruit pulp of mango and rose apple in the city of Cali (Valle del Cauca, Colombia) reflects a high richness and abundance of species, that varies according to the Brix degrees present in the fruit. The species $H$. opuntiae, $H$. thailandica and $\mathrm{Cl}$. lusitaniae were shared for both types of fruit and the genus Hanseniaspora was the most abundant for the rose apple. Two possible new species have been reported belonging to genera Wickerhamomyces and Pichia, associated 
with mango. Several species have been reported with biotechnological interest, either to produce enzymes or organoleptic compounds, or for the transformation of raw material into bioproducts. Finally, some yeast species are usually associated with decaying organic matter, so this type of yeast could colonize fruits for further degradation.

\section{ACKNOWLEDGMENTS}

This study was granted by Universidad del Valle (CI 7821). MRC thanks Colciencias-Colombia for providing the Post-Doctoral Fellowship (Conv. 784).

\section{AUTHOR CONTRIBUTIONS}

MRC, wrote the paper, analysed data; LMU, performed research; LMSB, analysed the data; EOC, conceived and designed the study.

\section{REFERENCES}

AUSUBEL FM. 2002. Short protocols in molecular biology: a compendium of methods from Current protocols in molecular biology. $5^{\text {th }}$ edition, New York: J Wiley \& Sons, $1512 \mathrm{p}$.

BARTRINA JA. 2006. Frutas, verduras y salud. Elsevier España, 268 p.

BAXTER AP AND VAN DER LINDE E. 1999. Collecting and Preserving Fungi. A manual for Mycology. Pretoria: ARC-Plant Protection Research Institute, Johannesburg, South Africa, $96 \mathrm{p}$.

BUENROSTRO-FIGUEROA J, TAFOLLA-ARELLANO JC, FLORES-GALLEGOS AC, RODRÍGUEZ-HERRERA R, DE LA GARZA-TOLEDO H AND AGUILAR CN. 2018. Native yeasts for alternative utilization of overripe mango pulp for ethanol production. Rev Argent Microbiol 50(2): 173-177.

CADEZ N, POOT GA, RASPOR P AND SMITH MT. 2003. Hanseniaspora meyeri sp. nov., Hanseniaspora clermontiae sp. nov., Hanseniaspora lachancei sp. nov. and Hanseniaspora opuntiae sp. nov., novel apiculate yeast species. Int J Syst Evol Microbiol 53: 1671-1680.

CARRILLO L. 2003. Microbiología Agrícola, Universidad Nacional de Salta, Salta, Argentina, $151 \mathrm{p}$.

CHI Z, WANG F, CHI Z, YUE L, LIU G AND ZHANG T. 2009. Bioproducts from Aureobasidium pullulans, a biotechnologically important yeast. Appl Microbiol Biotechnol 82:793-804.

CORTE L, DI CAGNO R, GROENEWALD M, ROSCINI L, COLABELLA C, GOBBETTI M AND CARDINALI G. 2015. Phenotypic and molecular diversity of Meyerozyma guilliermondii strains isolated from food and other environmental niches, hints for an incipient speciation. Food Microbiol 48: 206-215.

DEAK T. 2009. Ecology and biodiversity of yeasts with potential value in biotechnology. In Yeast Biotechnology: Diversity and Applications, Springer, Dordrecht, p. 151168.

DELLACASSA E, TRENCHS O, FARIÑA L, DEBERNARDIS F, PEREZ G, BOIDO E AND CARRAU F. 2017. Pineapple (Ananas comosus L. Merr.) wine production in Angola: Characterisation of volatile aroma compounds and yeast native flora. Int J Food Microbiol 241: 161-167.

DI FRANCESCO A, UGOLINI L, LAZZERI L AND MARI M. 2015. Production of volatile organic compounds by Aureobasidium pullulans as a potential mechanism of action against postharvest fruit pathogens. Biol Control 81: 8-14.

FEOLI M, GÓMEZ Z AND MUÑOZ A. 1997. Aislamiento y caracterización de microorganismos con actividad pectinolítica a partir de Mangifera indica. Rev Colomb Cienc Quim Farm 26(1): 33-37.

GANTER PF, MORAIS PB AND ROSA CA. 2017. Yeasts in cacti and tropical fruit. In Yeasts in Natural Ecosystems: Diversity, Springer, Cham, p. 225-264.

GAVIRIA J AND OSORIO E. 2012. Diversidad de levaduras asociadas a inflorescencias de mango y flores de "lulo arbóreo". Biotecnol Sector Agropecuario Agroind 10(2): 160-169.

GOSTINČAR C ET AL. 2014. Genome sequencing of four Aureobasidium pullulans varieties: biotechnological potential, stress tolerance, and description of new species. BMC genomics 15(1): 549.

GROENEWALD M, BOUNDY-MILLS K, ČADEŽ N, ENDOH R, JINDAMORAKOT S, POHL-ALBERTYN C, ROSA CA, TURCHETTI B AND YURKOV A. 2017. Census of Yeasts Isolated from Natural Ecosystem and Conserved in Worldwide Collections. In Yeasts in Natural Ecosystems: Diversity, Springer, Cham, p. 455-476.

GUAMÁN-BURNEO C AND CARVAJAL-BARRIGA J. 2009. Caracterización e identificación de aislados de levaduras carotenogénicas de varias zonas naturales del Ecuador. Univ Sci 14(2-3): 187-197.

JAGER ES, WEHNER FC AND KORSTEN L. 2001. Microbial ecology of the mango phylloplane. Microb Ecol 42(2): 201-207.

JINDAMORAKOT S ET AL. 2009. Three new species of bipolar budding yeasts of the genus Hanseniaspora and 
its anamorph Kloeckera isolated in Thailand. FEMS Yeast Res 9: 1327-1337.

KURTZMAN CP, FELL JW AND BOEKHOUT T. 2011. The yeasts: a taxonomic study. Elsevier Science, 2534 p.

KURTZMAN CP, MATEO RQ, KOLECKA A, THEELEN B, ROBERT V AND BOEKHOUT T. 2015. Advances in yeast systematics and phylogeny and their use as predictors of biotechnologically important metabolic pathways. FEMS Yeast Res 15(6): fov050.

KURTZMAN CP AND SUZUKI M. 2010. Phylogenetic analysis of ascomycete yeasts that form coenzyme Q-9 and the proposal of the new genera Babjeviella, Meyerozyma, Millerozyma, Priceomyces, and Scheffersomyces. Mycoscience 51(1): 2-14.

LI H, CHI Z, WANG X AND MA C. 2007. Amylase production by the marine yeast Aureobasidium pullulans N13d. J Ocean Univ Chin 6: 61-66.

LIMTONG S AND KOOWADJANAKUL N. 2012. Yeasts from phylloplane and their capability to produce indole3-acetic acid. World J Microbiol Biotechnol 28(12): 33233335 .

LIMTONG S AND NASANIT R. 2017. Phylloplane Yeasts in Tropical Climates. In Yeasts in Natural Ecosystems: Diversity, Springer, Cham, p. 199-223.

LÓPEZ-ARBOLEDA WA, RAMÍREZ-CASTRILLÓN M, MAMBUSCAY LA AND OSORIO-CADAVID E. 2010. Diversidad de levaduras asociadas a chichas tradicionales de Colombia. Rev Colomb Biotecnol 12(2): 176-186.

LU Y, CHAN LJ, LI X AND LIU SQ. 2018. Effects of sugar concentration on mango wine composition fermented by Saccharomyces cerevisiae MERIT. ferm. Int J Food Sci Technol 53(1): 199-208.

LUAN Y, ZHANG BQ, DUAN CQ AND YAN GL. 2018. Effects of different pre-fermentation cold maceration time on aroma compounds of Saccharomyces cerevisiae co-fermentation with Hanseniaspora opuntiae or Pichia kudriavzevii. Lebenson Wiss Technol 92: 177-186.

MACIEL NO, PILÓ FB, FREITAS LF, GOMES FC, JOHANN S, NARDI RM, LACHANCE MAAND ROSA CA. 2013. The diversity and antifungal susceptibility of the yeasts isolated from coconut water and reconstituted fruit juices in Brazil. Int J Food Microbiol 160(3): 201205.

MAMBUSCAY LA, LÓPEZ WA, CUERVO RA, ARGOTE FE AND OSORIO E. 2013. Identificación de las levaduras nativas presentes en zumos de piña, mora y uva. Rev Bio Agro 11(spe): 136-144.

MANZANARES P, RAMÓN D AND QUEROL A. 1999. Screening of non-Saccharomyces wine yeasts for the production of $\beta$-D-xylosidase activity. Int J Food Microbiol 46: 105-112.

MEJÍA LF, ALBÁN DC, MURCIA N, CUERVO R AND DURÁN J. 2009. Hidrólisis y fermentación alcohólica simultánea (HFS) del residuo agroindustrial del mango común (Mangifera indica L) utilizando levaduras Saccharomyces cerevisiae spp. y cepa recombinante RH 218. Guillermo de Ockham 7(2): 51-64.

MORAIS PB, MARTINS MB, KLACZKO LB, MENDONÇAHAGLER LC AND HAGLER AN. 1995. Yeast succession in the Amazon fruit Parahancornia amapa as resource partitioning among Drosophila spp. Appl Environ Microbiol 61: 4251-4257.

NAGAHAMA T. 2006. Yeast biodiversity in freshwater, marine and deep-sea environments. In Biodiversity and ecophysiology of yeasts, Springer, Berlin, Heidelberg, p. 241-262.

NISIOTOU AA AND NYCHAS GJE. 2007. Yeast populations residing on healthy or Botrytis-infected grapes from a vineyard in Attica, Greece. Appl Environ Microbiol 73: 2765-2768.

NIU C, YUE T, YUAN Y AND QIU Y. 2015. Isolation and identification of osmotolerant yeasts from quick-frozen kiwi fruit processing. J Food Saf Qual 6(7): 2722-2728.

OSORIO-CADAVID E, CHAVES-LÓPEZ C, TOFALO R, PAPARELLA A AND SUZZI G. 2008. Detection and identification of wild yeasts in Champús, a fermented Colombian maize beverage. Food Microbiol 25(6): 771777.

OSORIO-CADAVID E, RAMÍREZ M, LÓPEZ WA AND MAMBUSCAY LA. 2009. Estandarización de un protocolo sencillo para la extracción de ADN genómico de levaduras. Rev Colomb Biotecnol 11(1): 125-131.

PALNITKAR SS AND LACHKE AH. 1990. Efficient simultaneous saccharification and fermentation of agricultural residues by Saccharomyces cerevisiae and Candida shehatae. Appl Biochem Biotechnol 26(2): 151158.

PAMPULHA ME AND LOUREIRO V. 1989. Interaction of the effects of acetic acid and ethanol on inhibition of fermentation in Saccharomyces cerevisiae. Biotechnol Lett 11(4): 269-274.

POUBOL J AND IZUMI H. 2005. Physiology and Microbiological Quality of Fresh-cut mango Cubes as Affected by High-O2 Controlled Atmospheres. J Food Sci 70(6): m286-m291.

RAMÍREZ-CASTRILLÓNM, MENDES SDC, INOSTROZAPONTA M AND VALENTE P. 2014. (GTG) 5 MSP-PCR fingerprinting as a technique for discrimination of wine associated yeasts?. PLoS ONE 9(8): e105870.

RAMÍREZ-CASTRILLÓN M, MENDES SDC AND VALENTE P. 2017. South Brazilian wines: culturable yeasts associated to bottled wines produced in Rio Grande do Sul and Santa Catarina. World J Microbiol Biotechnol 33(4): 77. 
RAO RS, BHADRA B AND SHIVAJI S. 2008. Isolation and characterisation of ethanol-producing yeasts from fruits and tree barks. Lett Appl Microbiol 47(1): 19-24.

RODRIGUEZ ME, LOPES C, VALLES S, GIRAUDO MR AND CABALLERO A. 2007. Selection and preliminary characterisation of $\beta$-glycosidases producer Patagonian wild yeasts. Enzyme Microb Technol 41: 812-820.

RUIZ-MOYANO S, MARTÍN A, VILLALOBOS MC, CALLE A, SERRADILLA MJ, CORDOBA MG AND HERNANDEZ A. 2016. Yeasts isolated from figs (Ficus carica L.) as biocontrol agents of postharvest fruit diseases. Food Microbiol 57: 45-53.

SANTOS ARO, FARIA ES, LACHANCE MA AND ROSA CA. 2015. Ogataea mangiferae sp. nov., a methylotrophic yeast isolated from mango leaves. Int J Syst Evol Microbiol 65(6): 1855-1859.

SILVA-BEDOYA LM, RAMÍREZ-CASTRILLÓN M AND OSORIO-CADAVID E. 2014. Yeast diversity associated to sediments and water from two Colombian artificial lakes. Braz J Microbiol 45(1): 135-142.

SOMDA MK, SAVADOGO A, OUATTARA CAT, OUATTARA AS AND TRAORE AS. 2011. Thermotolerant and alcohol-tolerant yeasts targeted to optimize hydrolysation from mango peel for high bioethanol production. Asian J Biotechnol 3(1): 77-83.

STARMER WT AND ABERDEEN V. 1990. The nutritional importance of pure and mixed cultures of yeasts in the development of Drosophila mulleri larvae in Opuntia tissues and its relationship to host plant shifts. In: Ecological and evolutionary genetics of Drosophila. Springer, Boston, MA, p. 145-160.

SURESH ER, ONKARAYYA H AND ETHIRAJ S. 1982. A note on the yeast flora associated with fermentation of mango. J Appl Bacteriol 52(1): 1-4.

THIERFELDER S, OSTERMANN K, GÖBEL A AND RÖDEL G. 2011. Vectors for glucose-dependent protein expression in Saccharomyces cerevisiae. Appl Biochem Biotechnol 163(8): 954-964.

TING J, XU R AND XU J. 2018. Molecular Identification and Distribution of Yeasts in Fruits. In: Molecular Techniques in Food Biology: Safety, Biotechnology, Authenticity and Traceability, J Wiley \& Sons Ltd., p. 115-144.

TRINDADE RC, RESENDE MA, SILVA CM AND ROSA CA. 2002. Yeasts associated with fresh and frozen pulps of Brazilian tropical fruits. Syst Appl Microbiol 25: 294-300.

TRUJILLO LC AND ECHEVERRY S. 2015. Aislamiento y caracterización de levaduras presentes en el fruto del Syzygium malaccense (L.) Merr. \& L. M Perry (pomorroso) en la comuna 1 de la ciudad de Neiva-Huila. Ing Reg 13(1): 37-45.

TURK M AND GOSTINČAR C. 2018. Glycerol metabolism genes in Aureobasidium pullulans and Aureobasidium subglaciale. Fungal Biol 122(1): 63-73.
ULLOA J, LIBKIND D, FONTENLA S AND VAN BROOCK M. 2009. Levaduras fermentadoras aisladas de Cyttaria hariotii (Fungi) en bosques Andino-Patagónicos (Argentina). Bol Soc Argent Bot 44: 239-248.

URZI C, DE LEO F, PASSO CL AND CRISEO G. 1999. Intra-specific diversity of Aureobasidium pullulans strains isolated from rocks and other habitats assessed by physiological methods and by random amplified polymorphic DNA (RAPD). J Microbiol Methods 36: 95105.

VÁSQUEZ C, ALBERTO J, RAMÍREZ-CASTRILLÓN M, MONSALVE F AND ISABEL Z. 2016. Actualización en caracterización molecular de levaduras de interés industrial. Rev Colomb Biotecnol 18(2): 129-139.

VÉLEZ DU. 2009. Metagenómica ¿Una oportunidad para el estudio de la diversidad microbiana en Colombia? Rev Colomb Biotecnol 11(2): 4-7.

VU D ET AL. 2016. DNA barcoding analysis of more than 9000 yeast isolates contributes to quantitative thresholds for yeast species and genera delimitation. Stud Mycol 85: 91-105.

WONGWATANAPAIBOON J, KLINBUNGA S, RUANGCHAINIKOM C, THUMMADETSAK G, CHULALAKSANANUKUL S, MARTY A AND CHULALAKSANANUKUL W. 2016. Cloning, expression, and characterisation of Aureobasidium melanogenum lipase in Pichia pastoris. Biosci Biotechnol Biochem 80(11): 2231-2240.

YURKOV AM, KEMLER M AND BEGEROW D. 2011. Species accumulation curves and incidence-based species richness estimators to appraise the diversity of cultivable yeasts from beech forest soils. PLoS ONE 6(8): e23671, $1-9$.

\section{SUPPLEMENTARY MATERIAL}

Figure S1 - Phylogeny of yeast species in the Wickerhamomyces clade inferred from the D1/D2 domain of the LSU rRNA gene region. The tree backbone was constructed using Maximum Likelihood method. The best substitution model was TamuraNei $93(\mathrm{G}+\mathrm{I})$. Bootstrap percentages over 70\% from 1000 bootstrap replicates are shown. Bar $=0.2$ substitutions per nucleotide position.

Figure S2 - Phylogeny of yeast species in the Pichia clade inferred from the ITS region. The tree backbone was constructed using Maximum Likelihood method. The best substitution model was Kimura-2-Parameter $(\mathrm{G}+\mathrm{I})$. Bootstrap percentages over $70 \%$ from 1000 bootstrap replicates are shown. Bar $=2$ substitutions per nucleotide position. 